\title{
Estimating the Impact of Immigration on Wages in Ireland
}

\author{
ALAN BARRETT* \\ ADELE BERGIN \\ ELISH KELLY \\ Economic and Social Research Institute, Dublin
}

\begin{abstract}
We estimate the impact of immigration on the wages of natives in Ireland applying the technique proposed by Borjas (2003). Under this method, the labour market is divided into a number of skill cells, where the cells are defined by groups with similar ages and levels of education (or age and occupation). Regression analysis is then employed to assess whether the average wages of natives across skill cells is affected by the share of immigrants across cells. When the cells are based on education/age, our results suggest a negative relationship between native wages and immigrant shares. However, the opposite appears to hold when the cells are based on occupation/age. These contradictory findings suggest that care should be exercised when applying this method as inaccurate impressions of the impact of immigration on wages may arise.
\end{abstract}

\section{INTRODUCTION}

$\mathrm{D}$ uring the period of Ireland's remarkable economic boom, ${ }^{1}$ one of the notable features of the economic transformation was a rapid increase in inward migration. For much of its history, Ireland had experienced large population outflows but in the late 1990s significant inflows began. The rate

\footnotetext{
* Corresponding author: mailing address - Economic and Social Research Institute, Whitaker Square, Sir John Rogerson's Quay, Dublin 2, Ireland; Tel. + 3531863 2000; Fax. +353 1863 2100; e-mail: Alan.Barrett@esri.ie. We would like to acknowledge the funding provided by the Irish Research Council for the Humanities and Social Sciences under the Government of Ireland Thematic Research Project Grants Scheme. We would also like to acknowledge comments from Daniel Hamermesh, Stephen Drinkwater, an anonymous referee and colleagues at the Economic and Social Research Institute. The usual disclaimer applies.

${ }^{1}$ Roughly, the period of the boom lasted from 1994 (when real growth first exceeded 5 per cent) to 2007.
} 
of net inflow then increased through this decade, reaching a high point of almost 17 per thousand of population in 2006. Part of the high rate of inward migration was related to the attractive economic conditions that Ireland offered during its "Celtic Tiger" period. Another important dimension was the decision by the Irish government to allow full access to the Irish labour market when the EU expanded to 25 members on 1 May 2004. With the UK and Sweden being the only two other member states also allowing full access, much of the outflow from the new member states was channelled to Ireland.

The emergence of a significant population of immigrants in Ireland led to the production of a body of research which had two aims. First, from a domestic perspective, it was important for policymakers to have an understanding of the nature of the inflow which Ireland was experiencing and also of the outcomes for immigrants. In this context, studies looked at, amongst other things, the characteristics of immigrants (Barrett et al., 2006), their earnings (Barrett and McCarthy, 2007) and the extent to which they assimilated in the labour market (Barrett and Duffy, 2008).

The second aim of the research was international in its orientation and sought to augment the literature on immigration with lessons from the Irish case. Two features of Ireland's experience of immigration made it particularly interesting. First, the immigration had happened over the course of an economic boom. Second, much of the inflow was of people who, like the majority of the Irish natives, were (a) white and (b) Christian. It was expected that these two elements of the overall context would provide a positive environment for new arrivals. The findings of significant wage disadvantages (Barrett and McCarthy, 2007) and of little assimilation in the labour market (Barrett and Duffy, 2008) suggested that recently arrived immigrants faced difficulties, even in relatively favourable host countries.

In this paper we use the Irish case again, this time to explore the question of whether immigrants tend to increase or reduce the average wages of native workers. Clearly, the issue of immigration impacts is an enormously controversial issue in the public debate on immigration but also within the economics literature. As discussed in the literature review below, immigrants have been found to raise and lower the average wages of native workers, with many other studies finding no significant effects. Given this variety of results, the addition of a study using the Irish experience will be of value.

The approach we take is that which was proposed and applied by Borjas (2003) and applied again by Clark and Drinkwater (2009) and by Carrasco et al., (2008). In essence, we break the labour market up into a set of "skill cells", where cells are defined by combinations of age and education or occupation. We then explore whether the wages of natives within those cells are related to the share of immigrants in the cells, using data for the period 1999-2007. 
Borjas (2003) and indeed Clark and Drinkwater (2009) found a negative relationship between immigrant shares and the wages of natives. Carrasco et al. (2008) found no significant impacts. Hence, we had expected that our results would lie in the range of zero to a modest negative impact of immigration on native wages. However, our results actually show both a positive and a negative impact of immigrants on the wages of natives depending on whether skill cells are defined in terms of education or occupation. ${ }^{2}$ These are interesting results because they raise a question mark over the use of this approach to estimating the impacts of immigration.

The issue of the impact of immigrants on the wages of Irish workers has been addressed previously (Barrett et al., 2002 and Barrett et al., 2006). In both papers, the approach taken was to use an econometric model of the Irish labour market to simulate the impact of immigration, modelling the inflow as an exogenous increase in labour supply. The big limitation of that approach is that it does not provide direct evidence on the link between immigration and wages. In this paper, we attempt to provide direct evidence although, as mentioned above, a somewhat confusing set of results emerge.

The remainder of the paper is structured as follows. In Section II, we provide an overview of the literature on the wage effects of immigration, including Borjas (2003) upon which our empirical work is based. In Section III, we present some broad information on economic and labour market developments in Ireland during the period of our analysis, 1999-2007. In Section IV, we go on to describe how we implement the Borjas (2003) approach to estimating the impact of immigration on wages. In so doing, we describe the data which are used and how we construct skill cells. In Section V, we present our results. In Section VI, we discuss those results.

\section{THE LITERATURE ON THE WAGE EFFECTS OF IMMIGRATION}

Friedberg and Hunt (1995) provided a comprehensive review of work on the impact of immigration and it is helpful to draw on this in discussing work up to that time. ${ }^{3}$ They discuss how a number of approaches were taken to measuring impacts. One approach, labelled by Friedberg and Hunt as "cross section differencing", exploits the fact that the share of immigrants tends to differ across regions or cities. A simple regression relating immigrant shares and immigrant wages across cities or regions would suffer from an

2 As will be seen below, we control for potential endogeneity between immigrant inflows and wages.

${ }^{3}$ A more recent survey is provided by Dustmann, Glitz and Frattini (2008a). 
endogeneity bias, as immigrants are attracted to high wage cities. However, such a bias would be reduced if changes in the immigrant share were related to changes in wages. One example from the US is Goldin (1994); she found that a 1 percentage point rise in the immigrant share of a city reduces wages by between 1 and 1.6 per cent.

Recognising that differencing might not eliminate the endogeneity bias, others moved on to using instrumental variables in measuring immigrant impacts. For example, Card (2001) uses the fraction of earlier immigrants from the same source country to an occupation in a given city as an instrument for new immigrants. He finds that immigration by new immigrants decreased wages and employment rates in traditionally high immigrant cities by 1-3 per cent.

Another strand in this literature, again as labelled by Friedberg and Hunt (1995) is the exploitation of "natural experiments". Studies under this heading have analysed labour markets where a large and sudden inflow of immigrants has resulted mainly on foot of political decisions rather than through the more usual push and pull of economic forces. In this way, the endogeneity problem is again addressed. One example of this approach is that of Card (1990). He examined the impact of a 7 per cent increase in Miami's population in 1980 as a result of the sudden arrival of Cubans in May of that year. He found that only the wages of Cubans appeared to decline in response to this inflow.

Overall, Friedberg and Hunt (1995) conclude their review with the observation that "... the effect of immigration on the labour market outcomes of natives is small". ${ }^{4}$ However, in papers such as Borjas, Freeman and Katz (1997) a criticism was made of area-based studies that they failed to take account of a possible channel for adjustment, namely, the internal migration of natives. According to this view, the failure to find negative effects of immigration on wages could arise because of the outward migration of natives in response to immigration. Hence, migration impacts had to be estimated at a national level.

Borjas, Freeman and Katz (1997) implement a national level approach by simulating the impacts of migration, using estimates of factor price elasticities. They find that the location decisions of natives do respond to immigration. They also find that "... immigration has had a marked adverse impact on the economic status of the least skilled U.S. workers". The results in Borjas, Freeman and Katz (1997) suggested that the findings in other studies of small and/or insignificant effects of immigration on native wages may have been misleading.

${ }^{4}$ Borjas (2003) includes this same quotation. 
Borjas (2003) added to this view that immigration may have had more significant negative wage impacts. He looks at the effect of immigration on wages through the variation of the immigrant share across skill cells, where skills cells are constructed to group immigrants and natives with similar ages and levels of education. According to Borjas (2003) this approach overcomes the problem inherent in area-based studies of internal migration dampening any wages effects. In addition, it has an advantage over the simulation approach (used in Borjas, Freeman and Katz, 1997) in that it seeks to estimate directly the impact of immigration. As Borjas puts it “... for a given elasticity of substitution, the (simulation) approach mechanically predicts the relative wage consequences of supply shifts" (p. 1339). According to his estimates the immigration that occurred between 1980 and 2000, and which increased labour supply by 11 per cent, reduced the average native wage by 3.2 per cent. The approach was applied to the UK case by Clark and Drinkwater (2009); their results suggested that the immigration associated with EU enlargement may have reduced white native earnings by about 2.5 per cent.

A number of recent studies have seen the pendulum swing back again on the question of immigration and native wages. These studies have not produced findings in line with the Freidberg and Hunt (1995) summary of little or no impacts. Instead, they have found positive impacts of immigration on the average wages of natives. Ottaviano and Peri (2006a) ${ }^{5}$ describe themselves as "building on the model presented by Borjas (2003)" and placing the question in a general equilibrium framework where greater account is taken of the multiplicity of cross-elasticities across labour types and also between capital and labour. According to their results, over 90 per cent of the U.S. labour force gained from immigration. Similar conclusions are drawn in Ottaviano and Peri (2005 and 2006b), although the focus in these papers was on wage and other impacts across cities. ${ }^{6}$ Peri (2007) focuses on California but again finds a positive impact of immigration on wages. Dustmann et al., (2008b) consider the UK situation. Their approach is similar to some degree to Borjas (2003) in that skill-cells are created; however, immigrants and natives are grouped according to wages as opposed to the observable characteristics of age and education. They find positive wage effects of immigration.

How might it be possible that immigration could increase wages? If we assume that all workers are paid their marginal product, then any explanation for a positive impact of immigration on native wages must incorporate a positive impact of immigration on the productivity of natives.

\footnotetext{
${ }^{5}$ Borjas et al. (2008) contains a critical appraisal of Ottaviano and Peri (2006a).

${ }^{6}$ Card (2007) is another example of a paper which looks at the impact of immigration on wages across cities and also finds positive effects.
} 
One route through which this could occur is through complementarities between immigrant and native labour. Alesina and La Ferrera (2005) look at the issue from the perspective of cultural diversity and discuss how a group of diverse people can bring different perspectives to a problem-solving exercise, and thereby produce solutions which are superior to those arrived at by more homogeneous groups. While this line of reasoning is probably most relevant to high-skilled occupations, Ottaviano and Peri (2005) suggest that even in lower skilled occupations, immigrants and natives may not be perfect substitutes. As they put it: “... a Chinese cook and a U.S.-born cook or an Italian tailor and a U.S.-born tailor do not provide the same services" (p. 314). Recalling that the immigrant inflow into Ireland from the late 1990s onwards transformed the labour force in terms of national mix, the impacts of cultural diversity on the labour market could well be relevant.

The efficiency wage literature, and in particular Shapiro and Stiglitz (1984), prompts another possible route through which immigration may have impacted upon the productivity of Irish workers. If it is the case that native employees felt that the arrival of a highly flexible and hard-working cohort of immigrants threatened their existing positions, those native employees may have worked harder (or shirked less, in the language of Shapiro and Stiglitz, 1984). Blanchflower and Shadforth (2009) discuss how immigration may have lead to a fear of unemployment among UK workers and how this may have depressed wage demands. However, it seems reasonable to suggest that any "fear" which native workers experienced could have led to higher output just as readily as to lower wage demands.

Dustmann et al. (2008b) look to situations where there is a divergence between wages and marginal products in order to explain possible positive effects of immigration on wages. One of their scenarios, labelled "downgrading", envisages a situation in which highly skilled immigrants work in lower grade occupations and as a result have marginal products above their wages. If native workers can claim some of the surplus generated by immigrants, then positive effects of immigration on native wages become possible. As significant occupational downgrading has been observed for Ireland immigrants (Barrett et al., 2006; Barrett and Duffy, 2008), this scenario could well be relevant. ${ }^{7}$

As a final note, we consider the work that has been done within Ireland on the impact of immigration on wages. Barrett et al. (2002) and Barrett et al. (2006) base their approaches on Borjas, Freeman and Katz (1997) and use an econometric model of the Irish labour market to simulate the impacts of immigration. Barrett et al. (2002) show how immigration between 1996 and

${ }^{7}$ For a fuller discussion of some of the points raised above, see Lozano and Steinberger (2010). 
1999 was mainly of high-skilled individuals. According to their simulation, the wages of high-skilled people fell by 4.5 percentage points as a result of immigration over that period. Barrett et al. (2006) take a fuller account of the fact the immigrants are often employed in occupations below what would be predicted given their skill levels, and estimate that average wages were over 3 per cent lower in Ireland in 2003 as a result of the immigration in the decade prior to that.

Echoing a point quoted above when discussing Borjas, Freeman and Katz (1997), the estimates of the impact of immigration in Barrett et al. (2002) and in Barrett et al. (2006) must be viewed somewhat mechanical given that they are the output of a simulation exercise as opposed to direct measures of immigration impacts. In the following sections, we aim to provide direct evidence on the issue.

\section{RELEVANT FEATURES OF IRELAND’S ECONOMY, 1999-2007}

During the period 1999-2007, Ireland recorded exceptionally high rates of economic growth. The annual average growth rate was 5.7 per cent, with growth peaking at 9.2 per cent in 2000 . The annual rate of employment growth was just under 4 per cent. This meant that employment grew from 1.6 million in 1999 to 2.1 million in 2007, an increase of just over 30 per cent. The rate of unemployment averaged 4.4 per cent over this period and varied little around that mean, especially from 2002 onwards where the range of unemployment rates was 4.2 per cent (2002) to 4.5 per cent (2007).

Immigration was strong during the period. The rate of net inflow was 4.6 per thousand of resident population in 1999 but this grew to a rate of 17 per thousand in 2006. The corresponding figure for 2007, at 15.5 per thousand, represented a fall but this was still a large rate of inflow by international standards. One effect of this rate of inflow was to change dramatically the immigration share of Ireland's employees. In 1999, immigrants accounted for just 1.3 per cent of Ireland's employees. By 2002, this had risen to just under 5 per cent. By 2007, the share had reached 10 per cent.

As noted in the Introduction, favourable economic conditions provided a significant pull factor over this period. The decision to allow full access to its labour market from the date of accession (May 2004) to the new members of the European Union added a further impetus to the inflow. But even in the years prior to 2004, the Irish government had been facilitating an increase in inflows through an expansion of its work permit programme. In 1999, 6,250 permits were either issued or renewed. By 2003, this number had increased to 47,551 . 
Given that our interest is in the relationship between immigration and wages, it is useful to present the trend in the economy-wide wage between 1999 and 2007. Dividing the total non-agricultural wage bill, from the National Accounts, by the number of employees, we can see that nominal wages grew by 6 per cent on average each year between 1999 and 2007. The year of highest growth was 2000, when nominal wages grew by 7.7 per cent. But even in the year of lowest growth, 2007, wages grew by a strong 4.8 per cent.

\section{METHODOLOGY AND DATA}

The skills cell approach that we use to investigate the impact of immigrants on native Irish employees' earnings can be formally written as:

$$
Y_{i j t}=\beta P_{i j t}+\delta X_{i j t}+\varepsilon_{i j t}
$$

where $Y_{i j t}$ represents the mean value of native Irish workers' earnings who have education $\mathrm{i}$, age $\mathrm{j}$, and are observed in time period $\mathrm{t} ; P_{i j t}$, which is the explanatory variable of interest, captures the share of immigrants in a particular skills cell (ij) at time $t_{;}^{8} X_{i j t}$ is a vector of fixed effects that captures the skill group's education level, age and the time period to which the skill group relates to; and $\varepsilon_{i j t}$ is an error term.

Our dependent variable $\left(Y_{i j t}\right)$, is the mean of log hourly earnings of native employees in each skills cell and is constructed using earnings data from the 1999, 2000 and 2001 Living in Ireland Surveys and the 2004, 2005, 2006 and 2007 Surveys on Income and Living Conditions (SILC). 9 Our earnings data are inflated to 2007 prices using the Central Statistics Office's (CSO's) Consumer Price Index. Furthermore, we restrict our sample to the working age population (16 to 64 years of age), and we exclude self-employed individuals and those in full-time education. ${ }^{10}$ In Appendix II, we present individual-based descriptive statistics.

8 The immigrant share for a particular skill group is defined as: $P_{i j t}=M_{i j t} /\left(M_{i j t}+N_{i j t)}\right.$, where $M_{i j t}$ measures the number of immigrants in the skill cell $(\mathrm{I}, \mathrm{j})$ at time ${ }_{t}$, and $N_{i j t}$ gives the corresponding number of natives.

9 The Living in Ireland Survey was an annual survey conducted by the Economic and Social Research Institute (ESRI). It gathered information for individuals and households on a wide range of topics such as demographic and employment characteristics, education, health, etc. The Living in Ireland Survey formed the Irish component of the European Community Household Panel (ECHP). The same set of households and individuals were interviewed each year in which the survey was conducted, which was from 1994 to 2001. The SILC is also an annual survey, carried out by the Central Statistics Office (CSO), which gathers information on similar subject matter to the Living in Ireland Survey.

10 Irish nationals not born in Ireland are also excluded from the analysis. 
Our immigrant share variable $\left(P_{i j t}\right)$ was derived using immigration data from the Quarterly National Household Survey (QNHS) 11 for the years 1999 to 2001 and 2004 to 2007 (Q2). ${ }^{12}$ In this study, an immigrant is defined as an individual that was not born in Ireland and has been living in the country for between one and ten years. We use the QNHS so that our immigrant share variable is based on a much larger sample than is provided by the Living in Ireland Surveys or the SILCs. The number of observations upon which an immigrant share is based is never lower than 150. As a further guard against any possible small-sample bias, we also weight the regressions by the sample size of each cell.

In the skills cell approach, dividing the labour market up into separate education-age cells is motivated by the fact that workers with similar characteristics compete with each other in the labour market. However, recent research has shown that this particular partition may not be appropriate for a country like Ireland. Barrett, Bergin and Duffy (2006) find that although immigrants in Ireland have a higher level of educational attainment than natives they do not have a similar level of occupational attainment. A similar result has been found for immigrants in the UK (see Drinkwater et al., 2008). In addition, Barrett and Duffy (2008) find that this situation does not improve with length of residence in Ireland. Therefore, it may be the case that immigrants compete with natives within particular occupation-age groups in the labour market rather than within particular education-age groups. Hence, it may be more appropriate to conduct the analysis using occupation-age-time period cells.

Given the education-occupation mismatch issue described above, we construct two separate skill group datasets to investigate the impact of immigration on native Irish workers earnings. The first is based on educational attainment and age, while the second uses occupation combined with age to sort workers into different skill groups. For our education analysis, we define five distinct education categories: (i) primary-level or less, (ii)

11 The QNHS, which is a nationwide survey of households in Ireland, produces quarterly labour force estimates. Information is collected continuously throughout the year, with 3,000 households surveyed each week to give a total sample of 39,000 households in each quarter. Households participate in the survey for five consecutive quarters.

12 The QNHS offers one of the few large-scale surveys of immigrants in Ireland but it is also known that the survey undercounts the number of immigrants. This undercount may cause concern of non-representativeness in using QNHS data to analyse immigration issues. Furthermore, as the survey is only administered in English, there might be an additional concern that low-skilled immigrants are disproportionally omitted from the QNHS. However, research by Barrett and Kelly (2008) shows that the QNHS provides a reliable profile of Ireland's immigrants. In addition, they found that the QNHS over-estimates the proportion of low-skilled immigrants, which means that work based on this survey may slightly under-estimate the full contribution of immigration to the Irish economy. 
secondary-level, (iii) post-secondary, (iv) certificate or diploma, and (v) degree or higher. We also classify five age groupings. ${ }^{13}$ The five age categories are as follows: (i) aged 16-24, (ii) aged 25-34, (iii) aged 35-44, (iv) aged 45-54, and (v) aged 55-64. We have seven calendar years, which gives rise to 175 skill cells for our education analysis. In terms of our occupation skill cells dataset, we distinguish five occupations: (i) professional and manager, (ii) clerical, (iii) services, (iv) skilled, and (v) elementary. The five age categories used in the education analysis are employed here as well, along with seven calendar years, which results in 175 observations for our occupation analysis.

Figure 1: Immigrant Share by Educational Attainment, 1999-2001 and 2004-2007
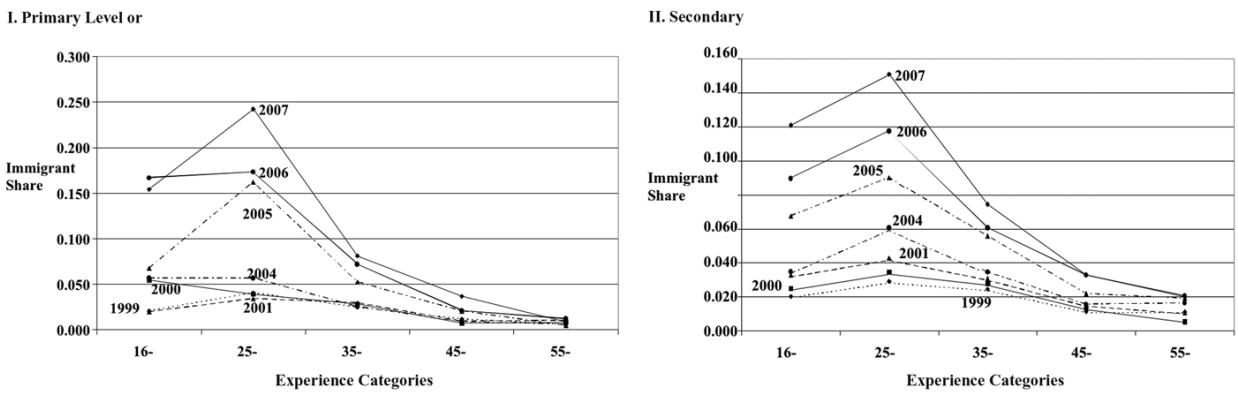

III. Post

IV. Certificate/Diploma
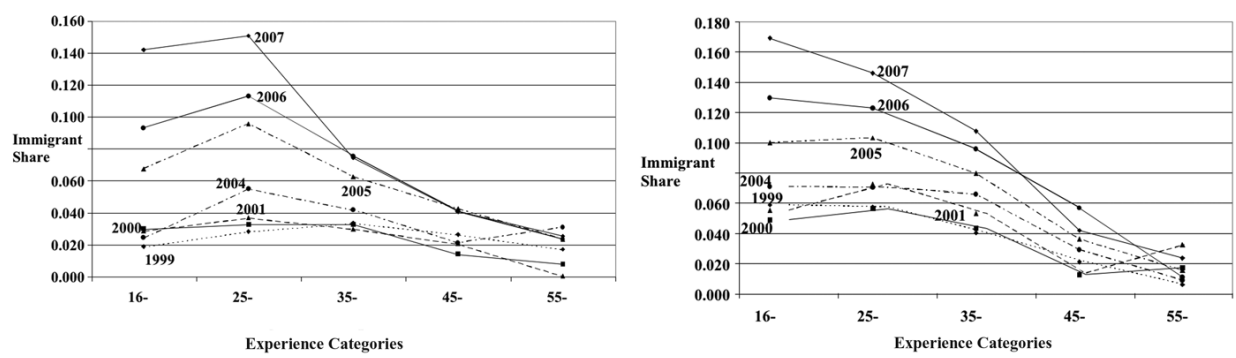

v. Degree or Higher

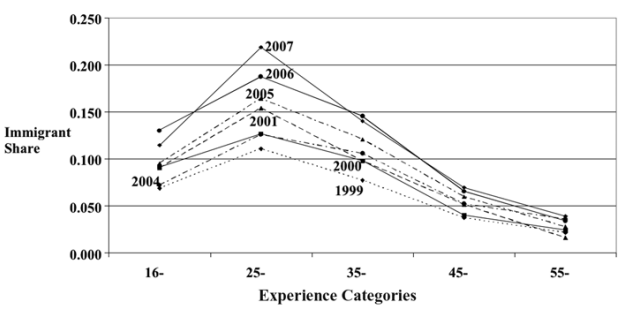

13 We are unable to construct a potential experience measure as the age information that is contained in the datasets used in the paper is banded (e.g. 15-24, 25-34, etc.). 
Figure 2: Immigrant Share by Occupation, 1999-2001 and 2004-2007
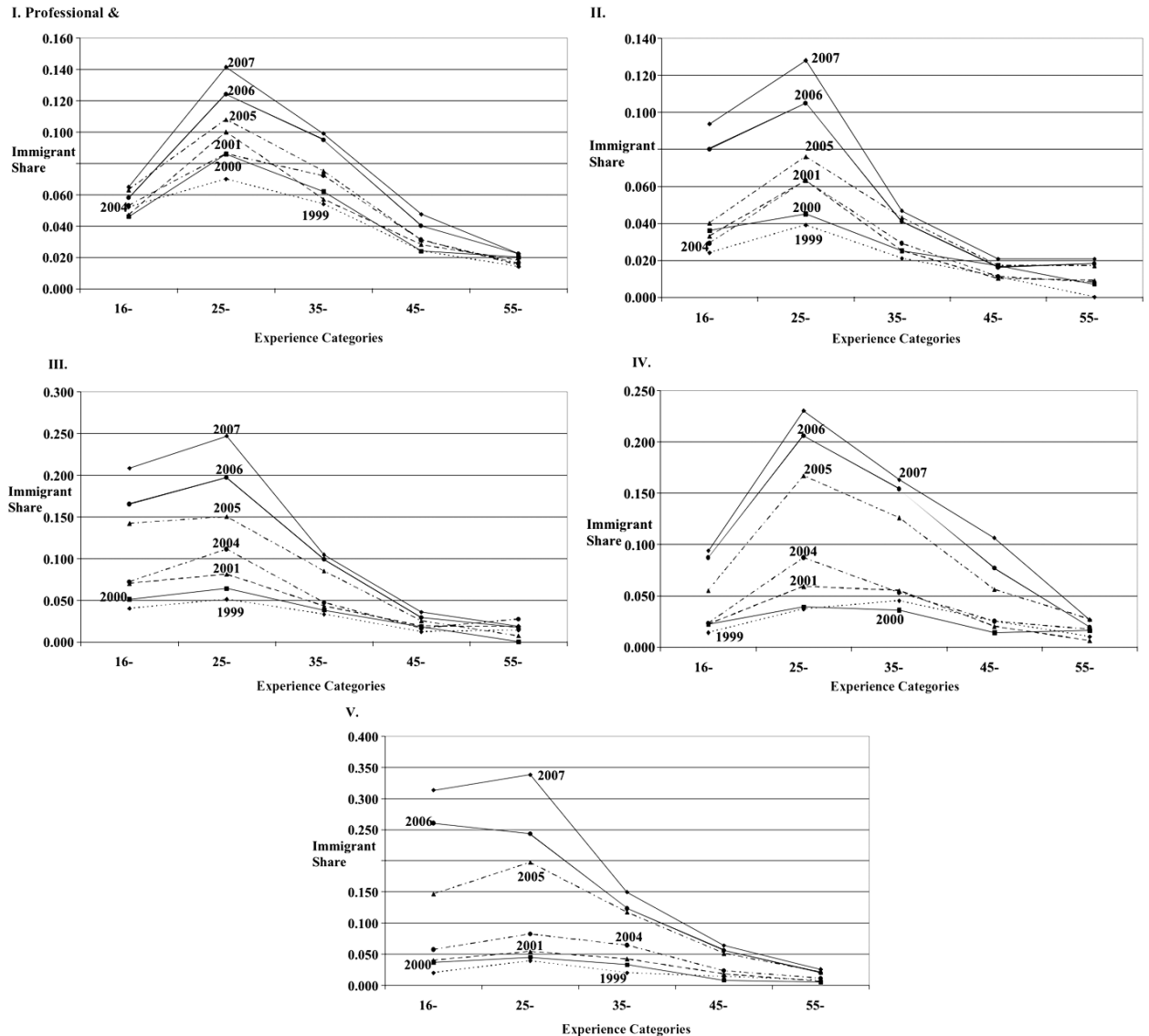

The five panels in Figure 1 plot the immigrant shares associated with our educational attainment skill groups for 1999 to 2001 and 2004 to 2007, while the panels in Figure 2 give a breakdown of the immigrant shares by occupation. The first point to note from Figures 1 and 2 is that there is significant variation in the immigrant share, both within and across the different education and occupation categories. Second, we can see that the biggest immigrant supply shocks took place in more recent years, specifically since EU enlargement in 2004, and that these shocks consisted mainly of younger immigrants (aged 25-34). Since 2004, the education skill group that has experienced the biggest immigrant supply shock is aged 25-34/PrimaryLevel or less. In 2004, immigrants made up only 5 per cent of this skill cell but by 2007 this had increased to almost 25 per cent. The other education skill 
group with the largest proportion of immigrants in 2007 is those aged 25-34 with a Degree or Higher (22 per cent). In relation to the occupation skill cells (Figure 2), since EU enlargement the biggest immigrant supply shock has been felt by those aged 25-34 in Elementary occupations. This cell consisted of only 8 per cent of immigrants in 2004 but by 2007 the share of immigrants had risen to 34 per cent. Natives aged 25-34 in Services and Skilled occupations have also experienced significant immigrant supply shocks since 2004.

Table 1 presents the real hourly earnings of native employees for the education skill groups, while Table 2 gives the breakdown for the occupation cells. As with the immigrant share, there is a considerable variation in the

Table 1: Real Hourly Earnings of Native Employees by Education Age Skill Cells, 1999-2001 and 2004-2007

\begin{tabular}{|c|c|c|c|c|c|c|c|c|}
\hline & $\begin{array}{c}\text { Age } \\
\text { Category }\end{array}$ & 1999 & 2000 & 2001 & 2004 & 2005 & 2006 & 2007 \\
\hline \multirow{5}{*}{$\begin{array}{l}\text { Primary-Level } \\
\text { or Less }\end{array}$} & $16-24$ & 11.21 & 6.50 & 8.87 & 11.71 & 9.81 & 9.70 & 9.73 \\
\hline & 25-34 & 11.23 & 9.75 & 11.95 & 10.56 & 10.60 & 11.12 & 12.10 \\
\hline & $35-44$ & 11.08 & 12.55 & 12.70 & 12.85 & 13.45 & 14.79 & 13.11 \\
\hline & $45-54$ & 11.94 & 12.37 & 12.71 & 13.60 & 13.83 & 12.96 & 13.95 \\
\hline & $55-64$ & 14.11 & 13.13 & 13.82 & 12.79 & 13.88 & 14.24 & 14.13 \\
\hline Secondary- & $16-24$ & 8.39 & 9.25 & 10.43 & 10.60 & 10.70 & 10.56 & 10.43 \\
\hline \multirow[t]{4}{*}{ Level } & $25-34$ & 12.18 & 12.46 & 13.41 & 13.56 & 13.36 & 14.36 & 14.63 \\
\hline & $35-44$ & 14.21 & 14.22 & 15.14 & 16.06 & 16.39 & 16.47 & 16.74 \\
\hline & $45-54$ & 15.91 & 16.09 & 16.14 & 17.01 & 17.62 & 17.65 & 17.42 \\
\hline & $55-64$ & 16.85 & 16.34 & 17.07 & 15.65 & 16.93 & 17.73 & 18.19 \\
\hline Post- & $16-24$ & 9.42 & 10.57 & 11.08 & 12.28 & 11.20 & 13.70 & 11.65 \\
\hline \multirow[t]{4}{*}{ Secondary } & $25-34$ & 11.70 & 13.12 & 12.90 & 15.53 & 15.21 & 15.41 & 16.40 \\
\hline & $35-44$ & 16.60 & 16.56 & 16.09 & 16.47 & 17.96 & 17.15 & 19.57 \\
\hline & $45-54$ & 10.55 & 15.64 & 18.27 & 17.54 & 17.99 & 16.85 & 19.44 \\
\hline & $55-64$ & 45.02 & 18.46 & 12.77 & 17.31 & 17.84 & 17.17 & 17.35 \\
\hline Certificate/ & $16-24$ & 12.12 & 10.78 & 12.37 & 12.53 & 12.56 & 13.39 & 11.48 \\
\hline \multirow[t]{4}{*}{ Diploma } & $25-34$ & 14.78 & 15.76 & 17.50 & 16.82 & 17.25 & 16.94 & 17.48 \\
\hline & $35-44$ & 20.99 & 19.49 & 19.20 & 20.24 & 21.37 & 21.22 & 22.84 \\
\hline & $45-54$ & 21.92 & 20.77 & 20.92 & 22.08 & 25.33 & 26.00 & 25.01 \\
\hline & $55-64$ & 26.89 & 22.77 & 24.56 & 24.10 & 24.81 & 25.27 & 24.24 \\
\hline Degree or & $16-24$ & 13.07 & 13.98 & 14.04 & 15.02 & 13.48 & 14.94 & 15.53 \\
\hline \multirow[t]{4}{*}{ Higher } & $25-34$ & 20.40 & 21.79 & 20.59 & 22.93 & 22.76 & 22.90 & 23.12 \\
\hline & $35-44$ & 31.67 & 27.30 & 30.61 & 30.01 & 30.66 & 31.79 & 31.14 \\
\hline & $45-54$ & 31.37 & 32.96 & 33.53 & 34.81 & 34.39 & 35.16 & 34.45 \\
\hline & $55-64$ & 31.35 & 31.94 & 34.38 & 32.59 & 33.79 & 35.73 & 37.18 \\
\hline
\end{tabular}


Table 2: Real Hourly Earnings of Native Employees by Occupation Age Skill Cells, 1999-2001 and 2004-2007

\begin{tabular}{|c|c|c|c|c|c|c|c|c|}
\hline & $\begin{array}{c}\text { Age } \\
\text { Category }\end{array}$ & 1999 & 2000 & 2001 & 2004 & 2005 & 2006 & 2007 \\
\hline Professional & $16-24$ & 12.90 & 12.51 & 13.12 & 15.82 & 13.43 & 15.47 & 15.26 \\
\hline \multirow[t]{4}{*}{ \& Manager } & $25-34$ & 18.63 & 19.47 & 19.88 & 21.59 & 21.00 & 21.52 & 22.06 \\
\hline & $35-44$ & 23.68 & 22.23 & 24.16 & 24.97 & 27.62 & 27.86 & 28.29 \\
\hline & $45-54$ & 26.19 & 25.68 & 25.80 & 27.88 & 29.45 & 30.61 & 30.69 \\
\hline & $55-64$ & 27.25 & 26.43 & 28.42 & 27.17 & 29.28 & 30.51 & 31.96 \\
\hline \multirow[t]{5}{*}{ Clerical } & $16-24$ & 9.30 & 9.99 & 11.60 & 11.47 & 11.40 & 11.14 & 11.05 \\
\hline & $25-34$ & 11.48 & 13.08 & 13.47 & 15.58 & 14.83 & 14.33 & 15.27 \\
\hline & $35-44$ & 13.86 & 14.32 & 15.25 & 16.20 & 16.73 & 17.57 & 18.26 \\
\hline & $45-54$ & 14.32 & 14.71 & 15.51 & 15.66 & 16.08 & 17.83 & 18.56 \\
\hline & $55-64$ & 16.89 & 13.51 & 16.51 & 17.02 & 15.57 & 16.04 & 17.52 \\
\hline \multirow[t]{5}{*}{ Services } & $16-24$ & 7.36 & 8.38 & 8.85 & 10.39 & 10.03 & 10.54 & 10.02 \\
\hline & $25-34$ & 10.15 & 10.78 & 11.56 & 13.19 & 13.65 & 13.89 & 13.72 \\
\hline & $35-44$ & 13.36 & 12.83 & 14.60 & 14.41 & 15.52 & 14.84 & 14.57 \\
\hline & $45-54$ & 12.19 & 12.58 & 13.11 & 14.10 & 14.44 & 14.86 & 13.14 \\
\hline & $55-64$ & 9.96 & 10.83 & 11.21 & 13.21 & 12.83 & 15.18 & 12.95 \\
\hline \multirow[t]{5}{*}{ Skilled } & $16-24$ & 8.70 & 8.94 & 10.61 & 9.86 & 10.43 & 10.53 & 11.06 \\
\hline & $25-34$ & 13.23 & 13.47 & 13.94 & 16.94 & 17.07 & 16.48 & 16.43 \\
\hline & $35-44$ & 14.84 & 14.35 & 16.06 & 17.52 & 18.06 & 20.21 & 20.32 \\
\hline & $45-54$ & 17.03 & 19.55 & 17.03 & 16.20 & 18.30 & 18.78 & 20.69 \\
\hline & $55-64$ & 13.51 & 15.27 & 16.52 & 15.28 & 16.67 & 18.17 & 17.66 \\
\hline \multirow[t]{5}{*}{ Elementary } & $16-24$ & 9.36 & 10.17 & 11.10 & 11.57 & 12.02 & 12.37 & 11.61 \\
\hline & $25-34$ & 11.48 & 11.65 & 12.81 & 13.60 & 13.63 & 15.09 & 15.00 \\
\hline & $35-44$ & 11.81 & 13.08 & 12.76 & 14.29 & 14.10 & 14.97 & 15.46 \\
\hline & $45-54$ & 11.85 & 12.23 & 14.05 & 14.40 & 14.24 & 14.36 & 14.76 \\
\hline & $55-64$ & 12.97 & 12.51 & 13.29 & 13.08 & 13.97 & 13.47 & 14.53 \\
\hline
\end{tabular}

natives' earnings for both the education and occupation skill cells. In relation to the education skill groups (Table 1), almost all the defined cells have experienced some growth in their real hourly earnings between 1999 and 2007. The main exception to this, however, is the group aged 16-24 with Primary education: this category's hourly wages grew up to 2004 but since then they have declined. Natives aged 25-34 with Post-Secondary education experienced the largest growth in hourly earnings over the time period analysed, with their earnings increasing from $€ 11.70$ in 1999 to $€ 16.40$ in 2007. In relation to the occupation groups, the hourly earnings of all the categories grew between 1999 and 2007. However, certain groups appear to have experienced a moderation in their earnings growth from 2004 onwards, for example, those aged 25-34 in Skilled occupations. 


\section{RESULTS}

\subsection{OLS Results}

We begin by presenting results from OLS regressions but below we conduct additional analyses which deal with the standard endogeneity issue which characterises studies of this type. Table 3 reports the results from an OLS regression where the dependent variable is the mean log real hourly

Table 3: Impact of Immigrant Share on Earnings of Natives Using Education-Age Groups*

\begin{tabular}{lccc}
\hline \hline & Coefficient & Robust Standard Error & $P>|Z|$ \\
\hline Immigrant Share & -0.438 & 0.434 & 0.32 \\
& & & \\
Educational Attainment & & & \\
(Ref = Primary-Level or Less) & & 0.021 & 0.00 \\
Secondary-level & 0.241 & 0.033 & 0.00 \\
Post-Secondary & 0.311 & 0.025 & 0.00 \\
Certificate/Diploma & 0.519 & 0.055 & 0.00 \\
Degree or Higher & 0.858 &
\end{tabular}

Age

$($ Ref $=$ Age 16-24)

Age 25-34

0.307

0.042

0.00

Age 35-44

0.495

0.047

0.00

Age 45-54

0.554

0.053

0.00

Age 55-64

0.558

0.057

0.00

Year

$($ Ref $=1999)$

2000

0.027

0.018

0.16

2001

0.086

0.029

0.01

2004

0.107

0.028

0.00

2005

0.137

0.029

0.00

2006

0.158

0.031

0.00

2007

0.172

0.035

0.00

Constant

1.952

0.046

0.00

Observations

R-squared

0.9650

F statistic

288.86

* Standard errors are adjusted for clustering within education-age cells. The regression is weighted by the sample size of the education-age-time period cells. 
wage for a native education-age group at a particular point in time. As expected, higher levels of educational attainment and age have a positive effect on native earnings. In addition, the year controls, intended to capture factors that affect all groups of workers but that change over time, have a positive impact. The key variable of interest is the immigrant share variable. The estimated coefficient is negative, implying that an increase in the immigrant share has a dampening effect on wages, but the coefficient is not statistically different from zero. This result implies that we are unable to find evidence that an increase in the share of immigrants affects the labour market earnings of natives.

Table 4 reports the estimated coefficient on the immigrant share variable when additional controls are included in the model. In the first specification, we include an interaction term between education and age to allow for the possibility that the effect of age on wages may differ across education groups. The second specification allows for an interaction between education and time as the returns to education may have changed over the time period, and the third specification includes an age and time interactions. Finally, the fourth specification includes all three sets of interactions. In each case, the estimated coefficient on the immigrant share variable remains insignificant and the estimate is negative in each specification apart from the model that just includes the education and age interaction.

Table 4: Estimated Coefficient on Immigrant Share with Additional Controls Included in the Model

\begin{tabular}{lccc}
\hline \hline & $\begin{array}{c}\text { Estimated Coefficient } \\
\text { on Immigrant } \\
\text { Share Variable }\end{array}$ & $\begin{array}{c}\text { Robust } \\
\text { Standard } \\
\text { Error }\end{array}$ & $P>|Z|$ \\
\hline 1. Education and Age Interaction & 0.182 & 0.202 & 0.38 \\
2. Education and Time Interaction & -0.515 & 0.483 & 0.30 \\
3. Age and Time Interaction & -0.991 & 0.965 & 0.32 \\
4. All Interactions & -0.178 & 0.456 & 0.70 \\
\hline
\end{tabular}

* Standard errors are adjusted for clustering within education-age cells. The regressions are weighted by the sample size of the education-age-time period cells. Each regression also includes controls for education, age and time.

Table 5 shows the regression results where the dependent variable is the mean log real hourly wage for a native occupation-age group at a particular point in time. As before, the results indicate that the wages of natives vary positively with age and over the time period considered in this paper. In addition, native workers with lower occupational attainment earn less than 
those with higher occupational attainment. The regression results also show that the estimated coefficient associated with the main variable of interest, the immigrant share variable, is positive and highly significant. This implies that the inflow of immigrants has served to increase the wages of native workers. ${ }^{14}$ This finding of a positive effect of immigration on outcomes for

Table 5: Impact of Immigrant Share on Earnings of Natives Using Occupation-Age Groups*

\begin{tabular}{|c|c|c|c|}
\hline & Coefficient & $\begin{array}{c}\text { Robust Standard } \\
\text { Error }\end{array}$ & $P>|Z|$ \\
\hline Immigrant Share & 0.735 & 0.203 & 0.00 \\
\hline \multicolumn{4}{|l|}{$\begin{array}{l}\text { Occupational Attainment } \\
\text { (Ref = Professional \& Manager) }\end{array}$} \\
\hline Clerical & -0.444 & 0.039 & 0.00 \\
\hline Services & -0.625 & 0.040 & 0.00 \\
\hline Skilled & -0.431 & 0.045 & 0.00 \\
\hline Elementary & -0.585 & 0.052 & 0.00 \\
\hline \multicolumn{4}{|l|}{$\begin{array}{l}\text { Age } \\
(\text { Ref = Age 16-24) }\end{array}$} \\
\hline Age $25-34$ & 0.257 & 0.059 & 0.00 \\
\hline Age $35-44$ & 0.431 & 0.056 & 0.00 \\
\hline Age $45-54$ & 0.490 & 0.066 & 0.00 \\
\hline Age 55-64 & 0.474 & 0.078 & 0.00 \\
\hline \multicolumn{4}{|l|}{$\begin{array}{l}\text { Year } \\
(\text { Ref }=1999)\end{array}$} \\
\hline 2000 & 0.022 & 0.014 & 0.12 \\
\hline 2001 & 0.082 & 0.016 & 0.00 \\
\hline 2004 & 0.126 & 0.019 & 0.00 \\
\hline 2005 & 0.130 & 0.016 & 0.00 \\
\hline 2006 & 0.152 & 0.019 & 0.00 \\
\hline 2007 & 0.148 & 0.021 & 0.00 \\
\hline Constant & 2.663 & 0.070 & 0.00 \\
\hline Observations & 175 & & \\
\hline R-squared & 0.9495 & & \\
\hline F statistic & 154.45 & & \\
\hline
\end{tabular}

* Standard errors are adjusted for clustering within occupation-age cells. The regression is weighted by the sample size of the occupation-age-time period cells.

14 Figure A1 in the Appendix plots the immigrant share against the earnings of natives and the figure indicates that there are no outliers in the dataset that could be driving the result. Figure A2 graphs native earnings and immigrant share by education-experience cells. 
natives is in line with the results of Ottaviano and Peri (2006a) and Dustmann et al. (2008b).

The estimated coefficient on the immigrant share variable is somewhat difficult to interpret; it is easier to do so if we convert it to an elasticity that gives the percentage change in hourly wages associated with a percentage change in employment. Following Borjas (2003), the wage elasticity is calculated as follows:

$$
\frac{\partial \log w_{i s t}}{\partial m_{i s t}}=\frac{\beta}{\left(1+m_{i s t}\right)^{2}}
$$

Where $m_{i j t}$ is the percentage increase of group $\left(_{i s t}\right)$ due to immigration. ${ }^{15}$ Over the time period we consider, the average immigrant share is 5.01 per cent so multiplying the estimated coefficient on the immigrant share variable by 0.907 yields a wage elasticity of 0.67 . This implies that a 10 per cent increase in the proportion of immigrants in a particular occupation-age group is associated with a 6.7 per cent increase in native wages.

We also include interaction terms between occupation and age, occupation and time and age and time. As before, we include each interaction term separately with the controls for occupation, age and time and all together with the controls for occupation, age and time. In each case, the estimated coefficient on the immigrant share variable remains positive and significant (see Table 6).

Table 6: Estimated Coefficient on Immigrant Share with Additional Controls Included in the Model

\begin{tabular}{lccc}
\hline \hline & $\begin{array}{c}\text { Estimated Coefficient } \\
\text { on Immigrant } \\
\text { Share Variable }\end{array}$ & $\begin{array}{c}\text { Robust } \\
\text { Standard } \\
\text { Error }\end{array}$ & $P>|Z|$ \\
\hline 1. Occupation and Age Interaction & 0.244 & 0.105 & 0.03 \\
2. Occupation and Time Interaction & 1.166 & 0.251 & 0.00 \\
3. Age and Time Interaction & 1.047 & 0.215 & 0.00 \\
4. All Interactions & 0.631 & 0.210 & 0.01 \\
\hline \hline
\end{tabular}

*Standard errors are adjusted for clustering within education-age cells. The regressions are weighted by the sample size of the education-age-time period cells.

In order for the OLS estimates to be consistent, we need the following to hold. First, there must be no skill-level labour demand shocks that lead to immigration. Second, there must be no skill-level native supply shocks. Third, 15 Note the immigrant share approximates $\log m_{i s t}$. 
there must be no native migration between skill groups in response to immigration. The second and third conditions can be thought of as an assumption of fixed group membership. While it is plausible that this assumption would hold for education-groups, it is less likely to hold for occupations because people switch occupations and may do so in response to immigration. If the assumption is violated in practice, then the occupationbased analysis here is likely to lead to inconsistent estimates.

In order to explore the possible impact of occupational mobility, we first assessed whether it was a significant feature within our data. It turned out that this was the case - for example, of the 1,116 people who were in all three waves of the 1999-2001 Living in Ireland Surveys, almost 30 per cent changed occupation category. Given the presence of occupational mobility, we created a new data-file in which an individual's occupation is fixed to be whatever occupation they had when they entered the panel. We then re-ran the analysis shown in Table 5. The results did not change - the coefficient on the immigrant share variable remains positive and significant. ${ }^{16}$

As a further robustness check, we also restricted the analyses to those aged 25 to 54 . For the youngest group, education and occupation changes are likely to be more prevalent. For the oldest age group, early retirement could be a complicating factor. The results in Tables 3 and 5 did not change, with the small exception that the positive and significant coefficient in the occupationbased analysis was significant at the 5 per cent level and not the 1 per cent level.

Our final robustness check involved the splitting of the data along gender lines. The particular concern in this context is that the increase in female participation over the period in question could bias the results. The general pattern of results remains the same. For men, as is the case in Table 3, the coefficient on immigrant share in the education-based analysis is not statistically different from zero. For women, a negative coefficient emerges but this is on the margins of significance (not significant at the 5 per cent level but significant at the 10 per cent level). In the case of the occupation-based analysis, the positive and significant finding remains for men - for women, the sign of the coefficient remains positive but it is no longer significant.

\subsection{Controlling for Endogeneity}

An important consideration to take into account is the fact that immigrants from certain education or occupational groups may have endogeneously chosen to locate in Ireland due to the wages that were being

16 We are grateful to a referee for pointing out this possible source of inconsistency in our coefficient estimates and for proposing the solution which we implemented. 
earned there in the corresponding education and occupation groups. This may have led to a spurious positive correlation between immigrant shares and wages in the occupation-based analysis. Following Goldin (1994), if the decision of immigrants to locate in Ireland is based on the wage level in their education or occupation group and not on anticipated increases in those wages, then this endogeneity problem can be overcome by estimating the regression equation with the change in wages as the dependent variable rather than the level. The change in immigrant share is then used as an independent variable. If the wage level in Ireland is the key determinant of the decision to locate in Ireland, then the change in the immigrant share will not be affected by the change in wages.

Tables 7 and 8 show the results of the differences estimation for the education-age analysis and the occupation-age analysis respectively. In each specification the estimated coefficient on the immigrant share variable is negative, yet it is only significant in a few specifications. The estimated negative impact of the change in the immigrant share casts doubt on the previous results found in the occupation-age analysis as we are unable to find evidence of an effect of immigration on wages here.

Table 7: Estimates of the Impact of Change in Immigrant Share on the Change in Earnings of Natives Using Education-Age Groups*

\begin{tabular}{lccc}
\hline \hline & $\begin{array}{c}\text { Estimated } \\
\text { Coefficient on } \\
\text { Immigrant } \\
\text { Share Variable }\end{array}$ & $\begin{array}{c}\text { Robust } \\
\text { Standard } \\
\text { Error }\end{array}$ & $P>|Z|$ \\
\hline 1. Base Specification (No Interactions) & -0.931 & 0.502 & 0.076 \\
2. Education and Time Interaction & -1.185 & 0.171 & 0.019 \\
3. Age and Time Interaction & -0.164 & 0.641 & 0.801 \\
4. Education and Age Interaction & -0.936 & 0.562 & 0.109 \\
5. Base Specification and All Interactions & -0.349 & 0.777 & 0.658 \\
\hline \hline
\end{tabular}

* Education, age and year controls are included in all specifications. Results on the other covariates that are included in the five different specifications are available from the authors on request.

Instrumental variable (IV) estimation is another procedure that has been adopted in the literature to deal with the issue of endogeneity (see for example, Card, 2001). In order to apply this methodology, we need an instrument that is highly correlated with our endogenous immigrant share variable $\left(\mathrm{P}_{\mathrm{ijt}}\right)$ but not wages $\left(\mathrm{Y}_{\mathrm{ijt}}\right)$. To create such an IV we use lagged immigrant share data $\left(\mathrm{P}_{\mathrm{ijt}-1}\right)$ to predict current shares $\left(\mathrm{P}_{\mathrm{ijt}}\right)$ and then include 
this predicted immigrant share variable in our wage models as an instrument for our endogenous immigrant share variable. ${ }^{17}$

Table 8: Estimates of the Impact of Change in Immigrant Share on the Change in Earnings of Natives Using Occupation-Age Groups*

\begin{tabular}{lccc}
\hline \hline & $\begin{array}{c}\text { Estimated } \\
\text { Coefficient on } \\
\text { Immigrant } \\
\text { Share Variable }\end{array}$ & $\begin{array}{c}\text { Robust } \\
\text { Standard } \\
\text { Error }\end{array}$ & $P>|Z|$ \\
\hline 1. Base Specification (No Interactions) & -0.480 & 0.314 & 0.139 \\
2. Occupation and Time Interaction & -0.422 & 0.284 & 0.151 \\
3. Age and Time Interaction & -0.097 & 0.280 & 0.732 \\
4. Occupation and Age Interaction & -0.737 & 0.411 & 0.086 \\
5. Base Specification and All Interactions & -0.151 & 0.520 & 0.775 \\
\hline \hline
\end{tabular}

* Occupation, age and year controls are included in all specifications. Results on the other covariates that are included in the five different specifications are available from the authors on request.

Table 9 shows the instrumental variable regression results when we use education and age to define our skill group, while Table 10 gives the results when occupation and age are employed. Education, age and year controls are included in all the specifications that are estimated in both tables. Focussing on our education results first (Table 9), we see from the base specification that our immigrant share variable is negative and significant, which suggests that the inflow of immigrants into the Irish economy has had a negative impact on native workers' hourly earnings. This result holds when education and time interactions (specification 2) and age and time interactions (specification 3) are included separately in the regression model, but not when education and age interactions are included (specification 4) or all the interactions together (specification 5).

When we turn to our occupation results, a different picture emerges. This time we find that when we use occupation to define our skill cells that immigration emerges as having a positive and significant impact on natives' hourly wages (specification 1). This positive outcome persists in all the occupation specifications that were estimated, apart from the occupation and age interactions model (specification 4). Hence, our results suggest that immigration tended to increase native wages when viewed along one

17 Results from the regression model used to create the IV used in this study (i.e., predicted immigrant share) are available from the authors on request. 
dimension of the labour market (occupation) and yet reduced wages when viewed along another dimension (education).

Table 9: Instrument Variable Estimates of the Impact of Immigrant Share on the Earnings of Natives Using Education-Age Groups*

\begin{tabular}{lcccc}
\hline \hline & $\begin{array}{c}\text { Estimated } \\
\text { Coefficient on } \\
\text { Immigrant } \\
\text { Share Variable }\end{array}$ & $\begin{array}{c}\text { Implied } \\
\text { Elasticity }\end{array}$ & $\begin{array}{c}\text { Robust } \\
\text { Standard } \\
\text { Error }\end{array}$ & $P>|Z|$ \\
\hline 1. Base Specification & -1.104 & -1.001 & 0.487 & 0.033 \\
$\quad$ No Interactions) & -1.180 & -1.070 & 0.561 & 0.046 \\
2. Education and Time Interaction & -1.775 & -1.610 & 0.771 & 0.030 \\
3. Age and Time Interaction & 0.137 & 0.124 & 0.247 & 0.583 \\
4. Education and Age Interaction & 0.319 & 0.289 & 0.476 & 0.509 \\
5. Base Specification and & & & & \\
$\quad$ All Interactions & & & & \\
\hline \hline
\end{tabular}

* Education, age and year controls are included in all specifications. Results on the other covariates that are included in the five different specifications are available from the authors on request.

Table 10: Instrument Variable Estimates of the Impact of Immigrant Share on the Earnings of Natives Using Occupation-Age Groups*

\begin{tabular}{lcccc}
\hline \hline & $\begin{array}{c}\text { Estimated } \\
\text { Coefficient on } \\
\text { Immigrant } \\
\text { Share Variable }\end{array}$ & $\begin{array}{c}\text { Implied } \\
\text { Elasticity }\end{array}$ & $\begin{array}{c}\text { Robust } \\
\text { Standard } \\
\text { Error }\end{array}$ & $P>|Z|$ \\
\hline 1. Base Specification & 0.548 & 0.497 & 0.210 & 0.015 \\
$\quad$ (No Interactions) & 0.985 & 0.893 & 0.271 & 0.001 \\
2. Occupation and Time Interaction & 0.840 & 0.762 & 0.237 & 0.002 \\
3. Age and Time Interaction & 0.148 & 0.134 & 0.150 & 0.335 \\
$\begin{array}{l}\text { 4. Occupation and Age Interaction } \\
\text { 5. Base Specification and }\end{array}$ & 0.696 & 0.631 & 0.341 & 0.053 \\
$\quad$ All Interactions & & & & \\
\hline
\end{tabular}

* Education, age and year controls are included in all specifications. Results on the other covariates that are included in the five different specifications are available from the authors on request.

\section{CONCLUSION}

Our application of the Borjas (2003) approach to measuring the impact of immigration on wages in Ireland has re-produced the Borjas finding of 
negative wage impacts but only when we base our skill cells on education. When we repeat the analysis but use occupation as the basis for the skill cells, we find evidence of a positive impact of immigration on wages. This is in contrast to Clark and Drinkwater (2009) who find a small, negative impact of immigration on wages in the UK using occupation as the basis of their skill cells. Hence, our contradictory results seem to be at odds with this strand of the literature.

While it might seem strange that we are finding two contradictory results using the same data, it should be remembered that the method used is not attempting to assess how the wage of the average native was affected by immigration. Instead, we are asking how average skill cells were affected. As the average education cell is not the same as the average occupation cell, contradictory results are possible, at least in principle. In order to explain the results, we would need to think in terms of substitution effects between immigrants and natives dominating in age/education cells but complementarity effects dominating in age/occupation cells.

While the contradictory results may be possible in principle, and while it might be possible to produce a theory to explain them, it could also be the case that something more mundane is at work, namely, spurious correlations. If this is the case, then the lesson of the paper is that the application of this method could have led us to assert mistakenly that there was evidence of wages being reduced (increased) by immigration in Ireland if we had restricted our analysis to education (occupation). This line of reasoning suggests that care needs to be taken when applying this method, or when interpreting results, to ensure that robust results are present.

\section{REFERENCES}

ALESINA, A. and E. LA FERRARA, 2005. "Economic Diversity and Economic Performance", Journal of Economic Literature, Vol. 43, No. 3, pp. 762-800.

BARRETT, A. and D. DUFFY, 2008. "Are Ireland's Immigrants Integrating into its Labour Market?", International Migration Review, Vol. 42, No. 3, pp. 597-619.

BARRETT, A. and E. KELLY, 2008. "How Reliable is the Quarterly National Household Survey for Migration Research?", Economic and Social Review, Vol. 39, No.3, pp. 191-205.

BARRETT, A. and Y. MCCARTHY, 2007. "Immigrants in a Booming Economy: Analysing their Earnings and Welfare Dependence", Labour: Review of Labour Economics and Industrial Relations, Vol. 21, No. 4-5, pp. 789-808.

BARRETT, A., A. BERGIN and D. DUFFY, 2006. "The Labour Market Characteristics and Labour Market Impacts of Immigrants in Ireland", The Economic and Social Review, Vol. 37, No. 1, pp. 1-26. 
BARRETT, A., J. FITZ GERALD and B. NOLAN, 2002. "Earning Inequality, Returns to Education and Immigration into Ireland", Labour Economics, Vol. 9, No. 5, pp 665-680.

BLANCHFLOWER, D. G. and C. SHADFORTH, 2009. "Fear, Unemployment and Migration”, Economic Journal, Vol. 119, (February), F136-F182.

BORJAS, G. J., 2003. "The Labor Demand Curve Is Downward Sloping: Re-examining the Impact of Immigration on the Labor Market", Quarterly Journal of Economics, Vol. 118, No. 4, pp. 1335-1374.

BORJAS, G. J., R. B. FREEMAN and L. F. KATZ, 1997. "How Much Do Immigration and Trade Affect Labor Market Outcomes?", Brookings Papers on Economic Activity, Vol. 1997, No. 1, pp. 1-90.

BORJAS, G. J., J. GROGGER and G. H. HANSON, 2008. "Imperfect Substitution between Immigrants and Natives: A Reappraisal", NBER Working Paper No. 13887.

CARD, D., 1990. "The Impact of the Mariel Boatlift on the Miami Labor Market", Industrial and Labor Relations Review, Vol. 43, pp. 254-257

CARD, D., 2001. "Immigrant Inflows, Native Outflows and the Local Labor Market Impacts of higher Immigration”, Journal of Labor Economics, Vol. 19, No. 1, pp. 22 64.

CARD, D., 2007. "How Immigration Affects U.S. Cities", CReAM Discussion Paper No. $11 / 07$.

CARRESCO, R., J. F. JIMENO and A C. ORTEGA, 2008. "The Effect of Immigration on the Labor Market Performance of Native-born workers: Some Evidence for Spain”, Journal of Population Economics, Vol. 21, pp. 627-648.

CLARK, K. and S. DRINKWATER, 2009. "The Labour Market Impact of Recent Immigration on Ethnic groups in the UK", Nordic Journal of Political Economy, Vol. 35.

DRINKWATER, S., J. EADE, and M. GARAPICH, 2009. "Poles Apart? EU Enlargement and the Labour Market Outcomes of Immigrants in the UK", International Migration, Vol. 47, No. 1, pp. 161-190

DUSTMANN, C., A. GLITZ and T. FRATTINI, 2008a. "The Labour Market Impact of Immigration”, Oxford Review of Economic Policy, Vol. 24, pp. 477-494.

DUSTMANN, C., T. FRATTINI and I. PRESTON, 2008b. "The Effect of Immigration along the Distribution of Earnings", CReAM Discussion Paper No. 03/08.

FRIEDBERG, R. M. and J. HUNT, 1995. "The Impact of Immigrants on Host Country Wages, Employment and Growth", Journal of Economic Perspectives, Vol. 9, No. 2, pp. 23-44.

GOLDIN, C., 1994. "The Political Economy of Immigration Restriction in the United States, 1890-1921" in C. Goldin and G. Libecap (eds.), The Regulated Economy: A Historical Approach to Political Economy, Chicago: University of Chicago Press.

LOZANO, F. A. and M. D. STEINBERGER, 2010. "Empirical Methods in the Economic of Immigration”, IZA Discussion Paper No. 5328.

OTTAVIANO, G. I. and G. PERI, 2005. "Cities and Culture", Journal of Urban Economics, Vol. 58, pp. 304-337.

OTTAVIANO, G. I. and G. PERI, 2006a. "Rethinking the Effects of Immigration on wages", NBER Working Paper No. 12497.

OTTAVIANO, G. I. and G. PERI, 2006b. "The Economic Value of Cultural Diversity: Evidence from U.S. Cities", Journal of Economic Geography, Vol. 6, pp. 9-44. 
PERI, G., 2007. 'Immigrants' Complementarities and Native Wages: Evidence from California", NBER Working Paper No. 12956.

SHAPIRO, C. and J. STIGLITZ, 1984. "Equilibrium Unemployment as a Discipline Device”, American Economic Review, Vol. 74, pp. 433-44. 


\section{APPENDIX I}

Figure A1: Log of Native Earnings and Immigrant Share by Occupation-Age Skill Cells

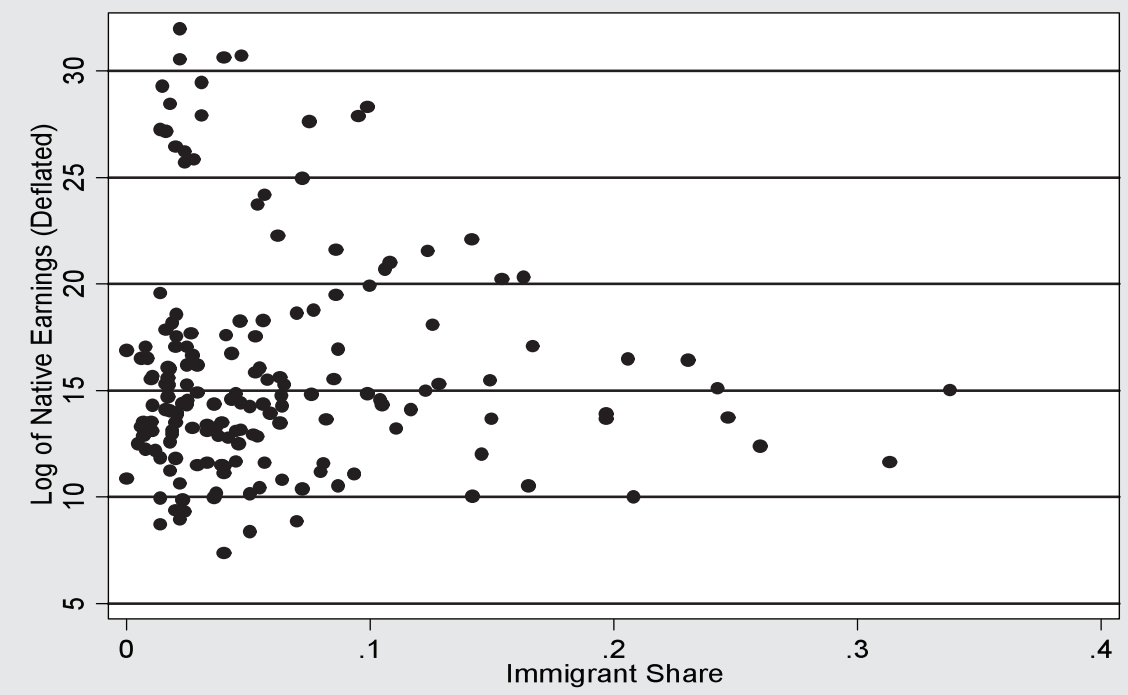

Figure A2: Log of Native Earnings and Immigrant Share by Education-Age Skill Cells

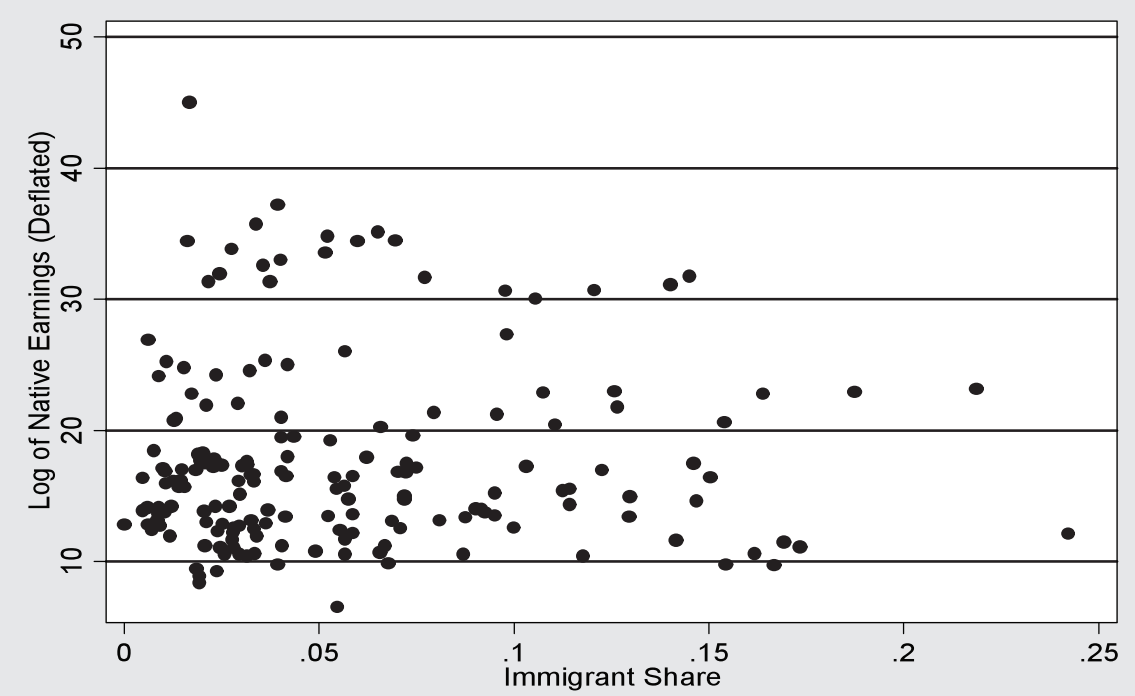




\section{APPENDIX II}

Table A1: Descriptive Statistics at Individual-Level for Natives, 1999-2001 (Living in Ireland Survey) and 2004-2007 (SILC)*

\begin{tabular}{|c|c|c|c|c|c|c|c|}
\hline & $\begin{array}{c}1999 \\
(\%)\end{array}$ & $\begin{array}{c}2000 \\
(\%)\end{array}$ & $\begin{array}{c}2001 \\
(\%)\end{array}$ & $\begin{array}{c}2004 \\
(\%)\end{array}$ & $\begin{array}{c}2005 \\
(\%)\end{array}$ & $\begin{array}{c}2006 \\
(\%)\end{array}$ & $\begin{array}{c}2007 \\
(\%)\end{array}$ \\
\hline \multicolumn{8}{|l|}{ Age Groups: } \\
\hline $16-24$ & 25.6 & 23.0 & 23.1 & 14.2 & 12.8 & 12.5 & 11.1 \\
\hline $25-34$ & 25.9 & 24.2 & 23.4 & 20.4 & 18.0 & 16.5 & 16.8 \\
\hline $35-44$ & 23.8 & 23.1 & 22.5 & 26.0 & 27.6 & 25.8 & 26.2 \\
\hline $45-54$ & 17.2 & 20.5 & 21.6 & 26.7 & 27.9 & 29.7 & 29.2 \\
\hline $55-64$ & 7.5 & 9.2 & 9.4 & 12.7 & 13.6 & 15.5 & 16.8 \\
\hline \multicolumn{8}{|l|}{ Education Level: } \\
\hline Primary-Level or Less & 7.7 & 7.1 & 6.9 & 11.7 & 12.0 & 11.2 & 11.2 \\
\hline Secondary-Level & 62.2 & 61.6 & 63.5 & 47.0 & 45.2 & 43.6 & 43.7 \\
\hline Post-Secondary & 4.7 & 5.0 & 3.7 & 10.0 & 9.8 & 10.6 & 9.3 \\
\hline Certificate/Diploma & 10.1 & 11.3 & 10.5 & 11.1 & 11.4 & 11.4 & 12.8 \\
\hline Degree or Higher & 15.3 & 15.0 & 15.4 & 20.3 & 21.6 & 23.1 & 23.0 \\
\hline \multicolumn{8}{|l|}{ Occupation: } \\
\hline Professional \& Manager & 33.1 & 33.8 & 33.0 & 34.7 & 35.5 & 36.4 & 36.3 \\
\hline Clerical & 13.2 & 13.6 & 14.8 & 15.9 & 15.5 & 15.7 & 17.2 \\
\hline Services & 17.8 & 16.9 & 17.3 & 19.5 & 19.4 & 19.6 & 19.2 \\
\hline Skilled & 12.7 & 13.5 & 12.8 & 10.8 & 9.6 & 9.2 & 9.2 \\
\hline Elementary & 23.2 & 22.2 & 22.1 & 19.1 & 20.0 & 19.0 & 18.1 \\
\hline Nominal Hourly Wage & $€ 10.76$ & $€ 11.76$ & $€ 13.02$ & $€ 15.88$ & $€ 16.99$ & $€ 18.40$ & $€ 19.63$ \\
\hline \multicolumn{8}{|l|}{ Nominal Hourly Wage } \\
\hline (Std. Dev.) & 6.78 & 6.92 & 7.53 & 9.08 & 9.57 & 10.91 & 11.50 \\
\hline Sample Size & 2,086 & 3,150 & 2,580 & 2,930 & 3,277 & 3,032 & 2,837 \\
\hline
\end{tabular}

* Descriptives based on labour force participant sample with the following categories excluded: (i) self-employed, (ii) students in full-time education, (iii) Irish nationals not born in Ireland, (iv) 'other' education individuals, and (v) those with missing education, occupation and earnings information. 